\title{
Environmental and ecological justice
}

Book or Report Section

Accepted Version

Okereke, C. and Charlesworth, M. (2014) Environmental and ecological justice. In: Betsill, M. M., Hochstetler, K. and Stevis, D. (eds.) Advances in International Environmental Politics. 2nd Edition. Palgrave Advances. Palgrave Macmilian, New York, pp. 123-147. ISBN 9781137338969 Available at http://centaur.reading.ac.uk/38520/

It is advisable to refer to the publisher's version if you intend to cite from the work. See Guidance on citing.

Published version at: http://www.palgrave.com/page/detail/advances-in-international-environmental-politics-michelem-betsill/?K=9781137338969

Publisher: Palgrave Macmilian

All outputs in CentAUR are protected by Intellectual Property Rights law, including copyright law. Copyright and IPR is retained by the creators or other copyright holders. Terms and conditions for use of this material are defined in the End User Agreement. 


\section{CentAUR}

Central Archive at the University of Reading

Reading's research outputs online 


\title{
13
}

\section{Environmental and Ecological Justice}

\author{
Chukwumerije Okereke and Mark Charlesworth
}

\section{Introduction}

Justice is a central theme in international environmental politics (IEP). In fact, one of the most distinctive contributions of IEP to the broader International Relations (IR) scholarship and discourse is arguably the firm insertion and elevation of questions of distributive justice. It is broadly accepted that justice occupies a central position in Western moral political philosophy. Hume (1975) described justice as the most important virtue of social relations and political institutions. St Augustine (1467/2003: 139) considered that the very legitimacy of a state lays on its claim to do justice. Rawls (1971) argued that any political institution deserves to be abolished if found to be unjust, because 'justice', he says, 'is the first virtue of social institutions' (3) and the 'rights secured by justice are not subject to political bargaining or the calculus of social interest' (5). Aristotle (1874/1998) regarded justice as co-extensive with virtue and therefore as the greatest of all virtues. 'In justice', he said, 'every virtue is comprehended'.

Despite the centrality of justice in political institutions and its potency as a 'tool for social political mobilization' (Okereke, 2008a: 32), IR scholarship has traditionally (and even now to a degree) failed to accord adequate concern to questions of justice. The conventional 
wisdom is that justice, to the measure that it can, should be focused on relations among people within national political boundaries rather than rigorously applied to IR (Caney, 2001).

However, from the contestations about fair distribution of putative proceeds from the exploitation of mineral resources in the seabed in the UN Third Law of the Sea (1967-1983), through disputes about how to balance between concerns for ecology and development (Stockholm and Rio), to current debates about how to share the burden of climate change, issues of equity and justice have certainly become one of the most contentious elements in the global sustainable development discourse. Yet, while the quest for environmental justice has played a central role in defining the character of international environmental rule-making over the last 30 years, these agitations have been generally less successful in upturning the fundamental structures and relationships that engender ecological degradation and environmental injustice.

There are at least three main reasons why justice is a very contentious and 'slippery' subject, especially in the context of IR. First, there are several dimensions of justice and the relationship between these aspects and frameworks for organizing the different dimensions are not always clear (Dobson, 1998). Notable aspects include distributional justice, which focuses on outcomes; procedural justice, which emphasizes how decisions are made; and compensatory justice, which is concerned with how to calculate and offset the effect of historical injustice. Other dimensions include intergenerational justice, which concerns justice between present and future generations, and interspecies justice, which deals with justice between human and non-human beings. Furthermore, there are gender, individual, community, national, and international dimensions of justice (Beck, 2008; Caney, 2005; Clark, 2008; Dobson, 2005; Page, 2011; Roberts and Parks, 2007; Skinner, 2011). The 
multiplicity of visions of an ecologically just world and the diverse array of voices and emphasis often raise the legitimate question of whether in fact it is 'possible to identify a single paradigm of environmental justice based on a common set of arguments' (Conca et al., 1995: 279). In fact, as we shall see below there are those who suggest making a distinction between environmental and ecological justice.

A second and related challenge is that despite the elegant definition proposed by Aristotle (1874/1998), - 'justice is giving to each their due' - it is still very difficult, even with the best effort, to decide what justice should look like in practice. The simple reason is that there are many different ways of deciding what is due to people, which correspond roughly to different conceptions of justice. Notable formulations include (1) advocacy of Equality of resource, of income, or of opportunity; (2) desert - for example, distribution on the basis of effort and/or merit; (3) need - distribution on the basis of need; (4) fairness - for example, behind Rawls' veil of ignorance or following 'The Golden Rule', which has versions in all societies, including 'do unto others as you would have them do unto you'; (5) property rights; and (6) utility or welfare maximization which emphasizes distribution to achieve the greatest happiness for the greatest number of people. Furthermore, not only does each of these conceptions of justice command decent ancestry and strong adherents, making any reconciliation difficult; most are developed in the context of national politics and transposing the core arguments to the international context is fraught with conceptual and practical difficulties. Hence, in many cases, any statement to the effect that one is interested in environmental justice immediately invites a riposte, 'which justice?' (see Dobson, 1998: $5)$.

A third major challenge is that IR, both in theory and practice, has developed in ways that tend to endorse the centrality of anarchy and self-interest. This development, alongside 
the weakness of institutions for addressing cross-border justice, often conspires to dampen even the best efforts to insert equity and justice in global (environmental) politics (Hurrell, 2001).

This chapter traces the evolution of key debates on international environmental justice and suggests important research frontiers. Although practical actions are yet to catch up with rhetoric, it is impressive that questions of ethics and justice can no longer be regarded as external or marginal concerns in global environmental governance (Biermann, this volume).

The next section gives an orientation to questions of justice, the environment, and IR, before the following sections look in some detail at more specific facets of these questions; specifically, justice and deep ecology, social ecology, 'empty-belly' environmentalism, intergenerational justice and procedural justice, before climate change is used as a case study to illustrate some of these aspects.

\section{Environmentalism, justice and IR}

Ideas about justice in one form or another have always been a feature of international politics. A world vision of justice and peace is at the heart of idealism as an IR theory (Bull, 1983; Viotti and Kauppi, 2011) and the establishment of key international institutions such as the United Nations and the International Labour Organization (ILO) (Pogge, 2001). Also the quest for justice underpins much of the anti-slavery, anti-colonization, and anti-apartheid movements in the 19th and 20th centuries, respectively (Bull, 1983; Nelson, 1974). However, to a large extent these concerns were muffled by the two World Wars and the dominance of realism which emphasizes power and relative self-interest as the key principles in IR. Moreover, the claims for justice as expressed in these movements were more about rights to self-determination than distributional in nature (Beitz, 1999; Nagel, 2005). 
Moral theories of IR were revived in the 1970s through the works of English School scholars like Hedley Bull, Barry Buzan, and Martin Wright, as well as through the writings of international political theorists such as Charles Beitz and Chris Brown. However, these theoretical endeavors quickly succumbed to revolutionary changes in global economic structures (Beitz, 1999: 515) and the dominant influence of liberal institutionalism, which emphasized the centrality of national economic interests, interdependence, and regime complexes in IR (Keohane, 1984; Viotti and Kauppi, 2011).

But while popular Western IR theorizing was dominated by power and self-interested assumptions, the vision of a more solidarist international society that incorporates adequate concerns for social justice remained strong in countries from the global south who had in the early 1960s set up the Non-aligned Movement and the Group of 77 (G77) to protest against prevailing global political systems of domination and to promote a more equitable international order (Willetts, 1978; Geldart and Lyon, 1980; Salter et al., 1993). It is therefore not surprising that as environmental issues gained ascendancy as a major topic for international cooperation in the late 1960s and early 1970s, developing countries wasted no opportunity to articulate 'clear and coherent reasons why the North stood to gain by discriminating in their favour' (Parks and Roberts, 2006: 331) regarding 'arguments about how responses to global environmental problems can be legitimized' (Paterson, this volume).

Although, as stated, concern for a just and more equitable international order has been a dominant theme in developing countries' approach to IR, they enjoyed more success with environmental issues for at least three reasons (cf. Okereke, 2008b). Firstly, environmental problems provoked a unique sense of urgency for international cooperation because they highlighted the close interdependence of humankind as well as our dependence on a single natural world regardless of national boundaries and geographies (Sachs, 1993, 1999). 
Critically, they highlighted the limited nature of political boundaries as causes and receptors of environmental pollution. Second, environmental issues created a heightened sense of vulnerability among the rich countries, and with that a sense of urgent need for global action (Beck, 1992, 1999). Thirdly, scholarly works like Silent Spring (Carson, 1962) and Limits to Growth (Meadows, et al., 1972) plus major environmental disasters, such as the Bhopal gasleak tragedy in India which killed over 3,000 people and the Chernobyl nuclear power plant disaster which affected millions, created a favorable 'normative temper' (Okereke, 2008b) for questions of justice in the international realm.

A particularly important set of events that helped to amplify and create a favorable 'moment' for International Environmental Justice (IEJ) was the anti-toxic waste dump movement in the United States (Bullard, 1983; Bryant and Mohai, 1992). The anti-toxic campaigns which started as a protest to block the dumping of contaminated soil in a poor and black-dominated area in North Carolina (Schlosberg, 2007: 47) soon broadened to include unequal exposure by class, race, and ethnicity. In addition to inspiring a wave of literature on the concept of environmental justice, the anti-toxic movement also produced emotive terms such as 'environmental racism', 'environmental genocide', 'toxic racism', and other vocabularies which provided important rhetorical devices and mobilization tools in the campaign for international environmental justice. In fact, from this time on, IEJ and questions of environmental justice at national levels were viewed as conceptually linked and resultant of the same systems of domination operating across different scales (Byrne et al., 2007; Conca et al., 1995; Elliott, 1998; Okereke, 2011).

As noted, environmental justice is far from being a unified or unifying concept. Right from the outset, the notion of environmentalism and its relationship with social justice has always been a hotly contested subject. It was not long after environmentalism became 
mainstream that various 'shades' of green movements or environmentalism were identified in scholarly literature and public discourse. To give just a limited view, O'Riordan in 1977 distinguished between 'conservative ecocentric' and 'liberal ecocentric' ideologies, and again in 1981 he made a distinction between 'ecocentric' and 'technocentic' modes of environmentalism. Sandbach (1980) differentiates between 'functionalist' and 'Marxist' environmentalism. Norwegian philosopher Arne Naess (1973) espoused a deep ecology philosophy which he set against the so called shallow ecology. Dobson's (1998) typology distilled four different types of environmentalism, including 'very weak sustainability', 'weak sustainability', 'strong sustainability', and 'very strong sustainability'. For Dobson, these four categories correspond to four environmental philosophies: Cornucopia, Accommodating, Communalism, and Deep Ecology. A provocative treatment by Guha and Martinez-Alier (1997) distinguishes between the 'full-stomach' environmentalism of the North and the 'empty-belly' environmentalism of the South. Paterson (2000) writing from an IR perspective separates between six categories, including liberal environmentalism, realism, ecoauthoritarianism, ecosocialism, social ecology and deep ecology.

Critically, these shades of green do not simply reflect varying emphasis on what is the most important aspect of environmentalism; rather many reflect fundamental (and sometimes irreconcilable) differences about worldview, and about the cause and solutions for global environmental problems (Dobson, 1998). In the following sections, we will trace the evolution of these ideas and their impact on IEP. A historical account is necessary because an understanding of how things came to be is often essential in comprehending the options for, and barriers against, achieving desired change (see also Stevis, this volume). As Pepper (1984) puts it,

if we seek for the future the kind of real social and environmental changes which much of the standard environmental literature calls for, ... then we must develop an 
historical perspective of how we and others have arrived at our present set of attitudes and understand what material changes will be needed to help foster a new one. (3)

For the sake of simplicity, we will limit ourselves to four broad categorizations and prevalent ideologies - all of which are mainly concerned with distributional aspects of justice. These are deep ecology, social ecology, 'empty-belly' environmentalism, and intergenerational justice. Subsequently, we will briefly discuss procedural justice, which is one distinct form of justice that has enjoyed a rise in recent times. Next, we will use the case of climate change to provide more practical illustration before making some concluding remarks.

\section{Deep ecology, justice and IR}

The notion of deep ecology as a concept and philosophical tradition has its roots in the life and works of Norwegian philosopher Arne Naess. In a seminal article in 1973, Naess criticized what he called the 'shallow range ecological movement', which he said was the prevailing ecological moment of the time. He argued that although powerful and influential, shallow ecology was very limited and in some cases outright dangerous. It was limited because it has as its central focus the fight against pollution and resource depletion, with the central motif being mainly the preservation of the health and affluence of people from the industrialized countries of the world. The shallowness of the movement lies, he argues, in its failure to grasp the deeper and intimate connection between man and nature. For Naess, shallow ecology can be outright dangerous because while purporting to recognize the importance of ecological thinking, policies inspired by this approach are not holistic but often result in displacing environmental harm, increasing the prices of life's necessities, increasing class divisions, and privileging economic growth over nature conservation. In short, then, this type of ecology is nothing but another form of utilitarian pragmatism by Western 
governments and businesses. Naess argued for a movement away from shallow ecology to deep ecology.

Deep ecology, according to Naess, recognizes the intimate interdependence between humankind and their ecology. The central claim is that humans are part of nature and not separate from it. Equally central is the notion that nature has an intrinsic or inherent value that is not based on its instrumental utility to humans. In fact, it advocates the doctrine of 'biospherical egalitarianism' (Naess, 1973: 95), which suggests that human beings and living nature each have equal right to life. Deep ecology rejects the domination of humans over nature to satisfy human wants, but rather presses the claim that humans have equivalent or at least near equivalent worth to nature. Following, it is suggested that a 'deep-seated respect [for nature], or even veneration' (Naess, 1973: 95) is required preferably from all, and most certainly from ecologists. Naess argues that deep ecology warrants a deeper recognition of the complexity of the world and a search for whole person and whole system solutions.

Although Naess is often linked to Buddhism because of his profession of Ghandian non-violence, it is in fact the case that his philosophy has a long and rich Western ancestry. In particular, his idea of deep ecology has close parallels with the writing and philosophy of many 20th-century Western ecologists, especially Aldo Leopold, the close friend and adviser to US President Theodore Roosevelt (Bowler, 1992). Leopold had in his book, A Sand County Almanac (2001), advocated a 'Land Ethic', which is based on the claim that humanity and all other beings are aspects of a single unfolding reality/community. Deep ecologists would tend to support Leopold's 'Land Ethic': 'a thing is right when it tends to preserve the integrity, stability and beauty of the biotic community. It is wrong when it tends otherwise' (Leopold, 2001: 189). According to Bowler (1992), Leopold's views and his influence on 
Roosevelt were very much instrumental to the establishment of the first wave of nature and game reserves in the United States and other parts of Europe.

What, though, is the connection between deep ecology and justice? To be sure, Naess did not use the term 'justice' in his seminal article setting out the key tenets of deep ecology. In fact, the term 'ecological justice' was apparently coined by Low and Gleeson as recently as 1998, though Conca et al. (1995) indicated the term. However, it is obvious that the deep ecology movement as elucidated by Naess has strong implications for justice both nationally and internationally. The rejection of human supremacy over nature or a domineering posture against nature is certainly at the heart of the idea of interspecies justice, which has been a key dimension of environmental ethics (Agar, 1997; Alder and Wilkinson, 1999; Brennan, 2003). A number of different broad arguments are used by philosophers to advance the claim for non-anthropocentric environmental ethics and to assert that non-human things are supposed to be included as subjects for justice (Baxter, 2005; Schlosberg, 2007). The first is the consequentialist approach, which draws mainly from utilitarianism and suggests that nonhuman things, especially those that can experience pain and pleasure, should be included in the community of justice (Regan, 1987; Singer, 1975). The notion that non-human things have intrinsic value and are deserving of justice consideration is the philosophical backbone for the animal rights movement, which has had considerable influence in relevant legislation and praxis in the Western democracies. The second is the deontological approach, the basic argument of which is that it is morally perverse for humans to destroy or dominate what they have not and cannot create (Alder and Wilkinson, 1999). Another strand is to argue that it is the whole biotic community (rather than individual species) that constitutes the community of justice (Callicott, 1989; cf. Leopold, 2001). The third approach is virtue, which emphasizes the role of ethical behavior such as moderation and prudence (Aristotle, 1874; MacIntyre, 1984). While deep ecology's main contribution to equity is seen to lie in the realm of 
interspecies justice, it should be pointed out that the philosophy also has implications for social justice at national and international levels. For example, Naess clearly identified egalitarianism and classlessness as key concerns for deep ecology. He wrote about the need to encourage diversity globally and promote an 'anti-class posture' both within and between nations. Moreover, his preference for local autonomy and decentralization both for production and, to the extent possible, for adequate political coordination has far-reaching implications for current globalized political and economic structures (see Byrne et al., 2007). It is hard to argue that deep ecology does not embody a concern for justice.

Nevertheless, deep ecology has been criticized precisely for failing to give adequate consideration to social justice at both the national and international levels. The most popular critique is arguably the one launched by Bookchin in his work, 'Social Ecology versus Deep Ecology: A Challenge for the Ecology Movement' (1987). Here, Bookchin criticizes deep ecology for paying too much attention to justice for nature while ignoring issues of social justice. He argues that deep ecology is in error for failing to recognize that ecological degradation was ultimately a reflection and manifestation of unequal and hierarchical social relations.

Another main strand of criticism which comes mostly from scholars from the South is the accusation that deep ecology stems from Western romanticism of nature and fails to adequately address questions of social justice, especially between rich and poor countries. Southern scholars point out that international environmental cooperation has not developed with adequate concern for distributive justice (Kiss, 1985; Okereke, 2008a). They argue that the focus has been more on conservation of endangered non-human species and less on distributive justice. Here it is frequently pointed out that the first set of international environmental agreements such as the Antarctic Treaty System (1959), the Ramsar 
Convention on Wetlands (1971), the London Convention on Dumping at Sea (1972), and the Convention on the Conservation of Migratory Species of Wild Animals (1979) have all been about conservation and less about human welfare. The argument is that attention to conservation masks the asymmetrical distribution of environmental benefits and burdens across nations. It is fair to say that while in principle deep ecology has radical implications for justice at national and international levels, the attention of the key proponents has been more on justice between human beings and nature. Deep ecology has important influence in the emergence and philosophy of some of the most globally influential non-governmental environmental organizations like WWF, IUCN, and Greenpeace (Bowler, 1992). These organizations had tremendous influence in bringing many environmental issues into the international agenda and some even took positions that had important consequence for justice (Betsill, this volume). However, these organizations have been criticized for not giving adequate attention to social justice, especially in relation to their support of programs such as debt for nature swaps, which tend to privilege biodiversity conservation over human welfare (Hamlin, 1989; Knicley, 2012). Deep ecology sentiments are still strong in the discourse and international environmental policymaking circles. Organizations such as Greenpeace and Friends of the Earth frequently attend important international conferences on environment to campaign for nature-centered views on policymaking. However, it is fair to say that for the most part their philosophy has shifted significantly from deep ecology sentiments to more of 'shallow ecology' or what Steven Bernstein (2001) calls 'liberal environmentalism'.

\section{Social ecology, justice, and IR}

Social ecology presses the claim that ecological problems are rooted in social problems and especially the social relations of hierarchy and domination (see also Detraz, this volume). Founded by green author and activist Murray Bookchin, the philosophy espouses the belief 
that it is impossible to address the world's ecological problems unless one fully recognizes that these problems are symptomatic of unequal social relations. Although critical of all forms of hierarchical relations (for example, gender, race), social ecology singles out classbased capitalism as the ultimate and most ecologically destructive form of hierarchical relations. Bookchin argues that capitalism pits man against man and results in the conversion of community relations to impersonal market relations where people are basically treated as commodities. The same logic results in various aspects of nature being treated as commodities that need to be exploited for instrumental reasons, especially market profit. Social ecology presses the claim for the need for more community, equality, and diversity. Like deep ecology, it argues for humanity to better recognize its relationship with nature; that is, recognize its place within as opposed to outside nature. Social ecology is very critical of solutions to ecological problems rooted in market transactions, such as green or ethical consumerism. It is suggested that such schemes mask the fundamental changes in structure of production that are required to achieve lasting ecological integrity. It argues for more decentralization and for democratic participation. Bookchin envisioned a post-capitalist society characterized by greater diversity, natural abundance, and participatory democracy, all of which he says will be made possible by technology.

As noted, social ecology is critical of deep ecology for focusing attention on humans' domination of nature and less on humans' domination over one another. Yet these traditions have far more in common than first meets the eye. Both believe in decentralization; both are against instrumental approaches to environmental conservation; both are critical of capitalism; and both believe in the need for greater diversity and equality. However, despite giving more explicit emphasis to unequal social relations in its thesis, social ecology does not dwell to any appreciable degree on international environmental justice. Bookchin's focus, 
like those after him, has been at the national level. Hence, it is subject to the same critique that Southern scholars make against deep ecology.

There is evidence that the philosophy of social ecology had at least indirect effect in promoting the quest for international environmental justice. For one, it certainly provided philosophical impetus for the campaign against environmental injustice that swept through the United States in the 1980s. However, given perhaps its focus on the national level, the influence of social ecology as a philosophy on IEP has been very limited.

\section{'Empty-belly' environmentalism, justice and IR}

By far the strongest source of agitation for international environmental justice has come from what Guha and Martinez-Alier (1997) describe as the 'empty-belly' environmentalism of developing country citizens and their political leaders. This environmental 'movement' has thrown up all sorts of difficult questions and made a serious impact on the direction and character of IR over recent years. As a result of this movement, it has now become almost unthinkable that any serious account of international relations will ignore the moral and ethical dimensions of international relations. Unlike deep and social ecology, both of which have as their focus social and ecological relations at the national level, the focus of 'emptybelly' environmentalism is squarely at the international level and in short the relationship between developed and developing countries. Although a coherent philosophical treatment is still lacking, agitation for international environmental justice by the South is based closely on three thematic rationales. These are discussed in the following.

\section{Unequal access to natural resources between the North and South}

Current and historical political economy structures mean that resources tend to be more readily available to Northern citizens and companies than those in countries with lower per 
capita income - typically in the South. Examples include energy, minerals, food, medicine, and clean water. The reasons for this situation are complex but certainly include historical factors such as colonialism and associated domination, exploitation, and abuses of power.

\section{The historical overuse of 'global commons' by the North}

It is often asserted (for example, WCED, 1987) that the atmosphere, deep oceans, and geosynchronous orbital space required for telecommunications satellites should be considered global commons that are not and cannot be owned by individuals or nations. In each case in the last few hundred years, Western nations have made more use of these resources than other nations with the vast majority of the benefits accruing. The clearest example is the emission of greenhouse gases (GHGs) such as carbon dioxide into the atmosphere, to which we return later in the chapter. Other examples include industrial whaling, fishing, exploitation of biological resources, and waste dumping in the oceans.

\section{Externalization of environmental risk by the North}

It is generally agreed that the risks associated with climate change caused by GHGs will fall principally on the poor in the South. A similar transfer of environmental risks is the movement of hazardous waste from North to South, which continues despite the Basel Convention (Okereke, 2008a).

In addition to the above, emphasis on the quality of participation in international environmental decision-making has grown in recent years, leading many commentators to focus on procedural equity as a separate dimension of justice which deserves close attention in the context of IEP. We provide a brief treatment later in the chapter.

\section{Intergenerational justice and environmental}

\section{relations}


The fourth dimension of distributional justice that has exerted important influence on the discourse of IEP is intergenerational justice. This is justice between present and future (as well as past) generations. The Brundtland report defines sustainable development as development that 'meets the needs of the present without compromising the ability of future generations to meet their own needs' (WCED, 1987: 53). This definition is an explicit endorsement that the idea of intergenerational justice is central to the notion of global sustainability. A number of popular maxims in the sustainable community also support the idea of intergenerational justice. One example is the famous Native American saying: 'Treat the earth well: it was not given to you by your parents, it was loaned to you by your children.'

However, while intergenerational environmental justice may have a powerful intuitive appeal, providing a robust philosophical justification of why unborn people should be considered a legitimate subject of justice is not easy (Page, 2007: 54). Perhaps the bestknown philosophical argument for attempting to establish the claim of intergenerational environmental justice is the indirect reciprocity thesis, which owes much to the work of Brian Barry (Barry, 1989; see Page 2007; Gosseries, 2006, 2008). Here the main argument is that the current generation owes something to the next generation because it received something from the previous one. In other words, because we received something from our parents we are obligated to pass the same 'in return' to our children. On this frame, justice also demands that the current generation must pass on to the next capital at least equivalent to what it inherited from the previous one, so that later generations should never 'be left worse off' (Barry, 1989: 159). One serious problem with this formulation however relates to the exact content of the capital that ought to be bequeathed to future generations - that is, whether it refers to natural resources, man-made resources, welfare, or social and technological capabilities. A related controversy is about whether these resources are commensurable and perfectly substitutable. In other words, is it fair for the present generation to exhaust resource 
$\mathrm{X}$ and compensate a future generation by leaving an abundance of resource Y? Some others reject the notion that future generations have rights and can be a legitimate community of justice on the ground that people yet unborn do not have identity and 'cannot now, therefore, be the present bearer or subject of anything including rights' (De George, 1981: 161).

Gosseries (2006, 2008) and Page (2006, 2007) among others have provided extensive treatments to show that considerations of justice across generations are implicated in important environmental policies, such as defining the level of a global cap on GHG emissions, deciding an emission reduction trajectory over time, justifying the preservation of biodiversity, conservation of species, setting a moratorium on whaling, and so on. This may well be the case. In fact as stated, leaving behind a decent planet for future generations constitutes a central tenet and impetus for environmental sustainability. However, it is less clear that this intuition is best cast in terms of justice or that such considerations are overly significant in international environmental decision-making quarters.

\section{Procedural environmental justice and IR}

The question of who has the power to participate and shape decisions has become increasingly crucial in global environmental governance literature (Auer, 2002; Betsill, this volume; Bulkeley and Mol, 2003; Clapp, 1998; Newig and Fritsch, 2009; Najam, 2005).

Although many comprehensive theories of justice include procedure and outcome (Miller, 1999; Nozick, 1974; Rawls, 1971), there is a growing tendency by commentators to give specific attention to procedural justice as an independent aspect of fairness in environmental politics (Adger et al., 2003; Newig and Fritsch, 2009; Paavola, 2005; ShraderFrechette, 2002). Ceva (2012) for one argues that fairness of governance systems and corresponding equity in participation should be a legitimate focus of justice and moral 
scrutiny independent of the outcomes of such systems. He contends that questions about the principles and fairness of participation remain expedient even where a governance system appears to produce just decisions and outcomes. Barry (1965) stressed the need to distinguish between fairness in the rules of participation and 'background fairness' where emphasis is on making sure that all parties have equal opportunity to participate under the set rules. This distinction is very crucial as will become evident below.

The United Nations and many international environmental regimes have elaborate rules of procedure which are often rigorously debated, suggesting states are mindful of the need for procedural justice. However, much of the focus appears to be on rules of process with little clarification of intended outcomes. Moreover, the huge asymmetry in numbers, technical, language, and informational capabilities, among other factors, all but makes a joke of this formal attempt to secure procedural justice defined narrowly as being present in meetings (see Najam, 2005; Roberts and Parks, 2007). Table 13.1 presents a head count of the number of delegates from select developed and developing countries (based on comparable populations) that attended the annual UN climate change meetings.

Table 13.1 Headcount of delegates from various countries who attended annual UN climate change meetings

\begin{tabular}{|c|c|c|c|c|c|c|c|c|c|c|}
\hline & $\begin{array}{l}\text { Chad } \\
\text { 11.2m }\end{array}$ & Germany & Ethiopia & $\begin{array}{l}\text { UK } \\
62.4 \mathrm{~m}\end{array}$ & $\begin{array}{l}\text { DR of } \\
\text { Congo }\end{array}$ & $\begin{array}{l}\text { Brazil } \\
\text { 190m }\end{array}$ & $\begin{array}{l}\text { Nigeria } \\
160 \mathrm{~m}\end{array}$ & $\begin{array}{l}\text { Canada } \\
34 \mathrm{~m}\end{array}$ & $\begin{array}{l}\text { Algeria } \\
\text { 36m }\end{array}$ & $\begin{array}{l}\text { Japan } \\
127 \mathrm{~m}\end{array}$ \\
\hline \multicolumn{11}{|c|}{65.9} \\
\hline 2000 & 2 & 75 & 5 & 41 & 2 & 66 & 15 & 81 & 8 & 69 \\
\hline 2001 & 2 & 56 & 3 & 37 & 2 & 40 & 19 & 46 & 8 & 98 \\
\hline 2002 & 2 & 54 & 3 & 43 & 2 & 30 & 8 & 54 & 6 & 73 \\
\hline
\end{tabular}




\begin{tabular}{|c|c|c|c|c|c|c|c|c|c|c|}
\hline 2003 & 1 & 62 & 0 & 38 & 2 & 55 & 13 & 66 & 14 & 76 \\
\hline 2004 & 1 & 46 & 2 & 47 & 6 & 207 & 18 & 71 & 13 & 81 \\
\hline 2005 & 1 & 48 & 2 & 83 & 7 & 34 & 9 & 371 & 11 & 70 \\
\hline 2006 & 1 & 45 & 0 & 40 & 3 & 15 & 7 & 48 & 1 & 39 \\
\hline 2007 & 5 & 101 & 2 & 64 & 9 & 196 & 31 & 61 & 8 & 75 \\
\hline 2008 & 2 & 57 & 2 & 42 & 2 & 17 & 11 & 33 & 2 & 54 \\
\hline 2009 & 2 & 31 & 7 & 22 & 7 & 34 & 27 & 24 & 11 & 55 \\
\hline 2010 & 10 & 110 & 28 & 75 & 58 & 736 & 83 & 93 & 27 & 135 \\
\hline
\end{tabular}

Note: Lead Author's head count from UNFCCC attendance register from unfccc.int/resource/docs

One quickly sees that even when huge technical advantages are discounted, the sheer numerical advantage of industrialized countries in these meetings leaves poor countries absolutely little or no chance to exert significant influence in decision-making. It should be noted that considerations of procedural justice in IEP extend beyond the balance of power and participation between developed and developing countries. Concerns have been raised about the extent to which states truly represent the various segments, interests, and communities that constitute them (Bäckstrand, 2003; Wapner, 1995, 1996). The lack of representativeness of states in IEP has also been voiced with particular reference to the interests of indigenous communities (Bäckstrand, 2006; Dove, 2006; Lane and Corbet, 2005). Other accounts have highlighted the need for gender balance in both national and 
international environmental governance (Bretherton, 2003; Bäckstrand, 2004; Detraz, this volume). In fact, one aspect of procedural injustice often identified in the literature is that while individuals, communities, and states alike have the ability to affect or be affected by environmental challenges, the legitimacy to decide solutions remains almost exclusively the preserve of nation-states (or more specifically, a few state-representing elites). In defense of the need to democratize global environmental spaces, some have suggested formal space should be created for transnational NGOs and subnational organizations such as cities to have greater say in global environmental decision-making (Bäckstrand, 2004, 2006; Cashore, 2002; Wapner, 2006, 2007; see also Betsill, this volume).

At the same time some have questioned the rationale for opening up international institutions to community groups, NGOs, and the like when these entities might themselves be in dire need of democratization (Lehr-Lehnardt, 2005; Jordan and Van Tuijl, 2000). Still others have questioned the justice of according equal vote to countries like the United States and Chad despite the huge difference in their population (Leech, 2002). There are no easy answers. However, questions about how best to democratize or achieve greater procedural justice in global environmental decision-making systems remains a priority in both theoretical and empirical terms (Farber, 2007; Tol, and Verheyen, 2004).

\section{Case study: climate change}

Climate change is a very good example for illustrating the role of justice in IEP and in particular the potential and limits of justice in global environmental governance. Although, as noted, demands for justice in global environmental rule-making have a fairly long history, climate change has provided the space and platform for the 'loudest' articulation of the need for justice in IEP in both policy and academic circles. In fact, it is fair to say that 
contestations for justice have been one, if not the most, defining feature of global climate policy since 1992.

There are at least two main reasons that account for the high-profile role of equity (a specific concern of justice) and justice (a broad term that typically has legal, political, and moral aspects) in global climate policy. The first is that climate change is implicated in fundamental developmental activities of all nations; thus the rules and policies adopted (or not) in addressing the challenge are bound to have serious consequences for the economy of nations. The second and related point is that climate change, with its massive negative impacts on natural, human, and social systems, has the ability to fundamentally alter the development path or options of many countries, especially those in the poorer regions of the world. In fact, for many countries in sub-Saharan Africa as well as several small island countries, climate change is an existential threat - holding out the possibility of forcing the entire country to relocate to new political territories (Biermann and Boas, 2010; Myers, 2002). These reasons are further amplified because of the huge asymmetry in contribution, impact, and decision-making abilities within and between countries.

In terms of impact, the vast proportion of the negative effects of climate change will be borne by the world populations that have least contributed to the problem. The implication is that climate change is essentially a case of the rich imposing their risks on the poor. Beyond that current decision-making processes and power structures mean that rich countries have advantages over poorer countries in the rather convoluted and complex process of deciding how to tackle the problem of climate change. This creates a distinct possibility that those responsible for the problem can use their decision powers to approve rules that further exacerbate their advantages. 
In extant scholarship, several dimensions of justice in the context of climate change have been articulated (Adger, et al., 2006; Gardiner, 2004; Grasso, 2007; Page, 2007;

Okereke and Schroeder, 2009). This ranges from two broad categories - justice in mitigation and adaptation - to 'ten layers' of justice as proposed by Parks and Roberts (2006). In our view, there are at least five practical justice challenges to which any global climate policy must respond. These include the following:

$<$ list $>$

(i) Justice in mitigation: Given the vast asymmetry in contribution to climate change between nations in both historical and current terms, plus the urgent need for drastic emission reductions, as indicated by climate science, how should the burden sharing for climate mitigation be best distributed within and between nations (Adger, 2001; Müller, 2001; Thomas and Twyman, 2005)?

(ii) Justice in adaptation: Given that the vast proportion of the negative impacts of climate change will be on the people who have contributed least to the problem, what is the most just way for distributing the limited finance and capacity for helping vulnerable communities and countries adapt, plus how should the cost for adaption be distributed within and between countries (Adger, 2001; Adger et al., 2006; Thomas and Twyman, 2005)?

(iii) Justice in procedure: Given the huge asymmetry in decision-making power within and between countries, what are just ways of ensuring effective participation in climate negotiation processes? Critically, how can the notion of effective participation be made applicable across scales of geography from communities, through states, to world regions (Thomas and Twyman, 2005; Adger et al., 2006; Vanderheiden, 2008)? 
(iv) Justice in compensation: Given that climate change is already having devastating impacts on the lives and development paths of many countries, especially in the poor South, what are just ways of calculating and providing adequate compensation for the victims of climate change (Farber, 2007; Smit and Skinner, 2002; Tol and Verheyen, 2004)?

(v) Justice in background political structures: Given that the asymmetries implicated in climate change (contribution, impact, ability to participate, and so on) are only symptomatic of broader and deeper structural inequities, what are just ways to address the deep causes of these fundamental inequities, in a bid to create a fairer world (Shue, 1992; Okereke, 2011)?</list>

In practice, these questions have been a regular feature of the climate regime since its inception in 1992. There is every indication that they will continue to dominate the effort to find a replacement for the new climate regime that will replace the Kyoto protocol in 2015.

In light of the above, the question then is what, if any, has been the role of the different environmental justice philosophies/movements in the development of the global climate regime? It is probably fair to say that deep ecology ideas are barely considered in climate policy. It is true that the target of climate stabilization is often discussed in the context of preventing irreversible damage to the natural ecosystem. However, what instrumental benefits humans can get from nature and threats to these benefits have almost exclusively been the concern. Thus any 'justice' - even gratitude as part of right relationship (cf. Barry, 1999: 263) - that might be owed to aspects of nature is barely considered in practice. More social aspects of deep ecology ideas, such as implications for social class, do have some consideration in climate change policy and discussions, if not explicitly labeled as such. 
Similarly, social ecology has had little explicit impact on climate policy. There is growing recognition that the climate problem has an intimate link with prevailing class-based capitalist structures and that the most vulnerable to climate change are those at the bottom of the ladder in the world capitalist structure. Despite this, however, the idea that the market and neoclassical development patterns provide the best way of addressing climate change remains extremely strong in policy and academic discourse. The central assumption is that climate represents nothing more than a market failure and that the best way to address it is to internalize the externalities and in so doing correct the inefficiencies that caused the problem. This explains why market instruments such as carbon taxes, emissions trading, the Clean Development Mechanism (CDM), rating and disclosure, joint implementation, and voluntary carbon offsets are by far the dominant instruments for addressing climate change. This practice barely considers the mounting scholarship, casting serious doubt on the efficiency and poor distributional impacts of these instruments (Böhm and Dabhi, 2009, 2011; Lohmann, 2009, 2010).

Predictably, empty-belly ecology has had the most effect on climate policy. Right from the outset, developing countries resisted the attempt by the North to make climate change a matter of narrow discussion about the technical mitigation or sequestration of carbon. In an intense diplomatic effort led mostly by Brazil, China, and India, the South insisted that global efforts to address climate change must be put in the broader context of equitable international development. In fact, they argued that effort to address climate change must be seen as a tool for correcting fundamental injustice in global economic structures (Borione and Ripert, 1994; Dasgupta, 1994). It was through these efforts that concepts like North-South financial and technology transfer, per capita emissions, historical emissions, capacity building, and most notably the common but differentiated responsibility principle became very common vocabularies within the regime's development circles. 
Yet, while there is evidence that the empty-belly ecology of the South has led to a very strong insertion of justice concerns in the climate regime, it is fair to say that actual practical policies aiming at achieving greater justice have at best had very marginal impact. The minimal evidence of such impact includes, firstly, the exclusion of the countries with historically low emissions from being required to undertake quantified emission reduction targets in the Kyoto regime. Secondly, there is the establishment of a climate adaption fund to help the Least Developed Countries (LDCs) deal with the negative impact of climate change. Thirdly, there is the CDM which provided opportunities for rich countries to make technological investments in developing countries in return for certified emission reduction (CER) credits. However, North-South transfers in the order of hundreds of billions of dollars originally envisaged from the outset of the global climate negotiations have not materialized (Grubb et al., 1991; Hayes, 1993). Nor has there been any radical change in the world capitalist and neoliberal system, which is responsible for climate destruction and Northern domination.

\section{Summary and conclusion}

Normative approaches to IEP have served to bring the 'unavoidability of justice' to mainstream scholarship and the forefront of global environmental policymaking. Concerted diplomatic effort and scholarship on this area have joined forces to overturn the notion that international politics is beyond the pale of morality and subject only to the calculus of egoistic and self-interested state actors. The impact of considerations of justice - deep ecology, social ecology, and most of all empty-belly ecological justice - litters the international environmental policy landscape. Yet, it remains the case that international diplomacy still tends in practice to support gains in wealth and power by those countries, companies, and individuals who already have power. Hence despite the central role of justice 
in international environmental policymaking and environmental studies scholarship, IR practice has so far failed to accord adequate concerns to questions of justice. As efforts to negotiate a new regime for climate change get under way, one of the interesting questions will be whether the new regime will build on the advances made or whether there will be significant regression.

Each of the facets of justice discussed here will bear sustained efforts to be applied to environmental policy in general and climate policy in particular, as justice questions, if not solutions, are clear in this field. Perhaps the most important are considerations of formal international procedures that address empty-belly environmental justice questions in the context of difficulties predicting the climate system (Charlesworth and Okereke, 2010), in particular, by gathering weight of evidence of the distribution approaches to justice and environmental ethics questions globally. This appears likely to suggest that policy and international agreements should be less focused on imposing maximization of economic growth and more focused on allowing the wealthy to live simply so that the poor and future generations can simply live. There is already evidence to suggest that more people in the world support moderate consumption rather than humans eating ourselves out of heart and home.

\section{Annotated bibliography}

Dobson, A. (1998) Justice and the Environment: Conceptions of Environmental Sustainability and Dimensions of Social Justice (Oxford: Oxford University Press).

A preeminent work which provides a detailed account of the relationship and trade-offs between different conceptions of environmental justice and various principles of social justice. It is the first book to robustly argue that while environmental sustainability and social justice may both be desirable social goals, these two objectives in reality are not always 
compatible or mutually reinforcing. A lot depends, at least in part, on Which conception of sustainability and to Which dimension of justice one subscribes.

Shue, H. (1992) 'The Unavoidability of Justice', in A. Hurrell and B. Kingsbury (eds) International Politics of the Environment: Actors Interests and Institutions (Oxford: Clarendon Press).

This is one of the earliest accounts that mounted a robust defense of the centrality of questions of justice in international environmental relations. The central argument is that questions of justice are not external to international environmental negotiations on three grounds. First is that negotiation between states takes place in the context of power asymmetry and conditions of 'background injustice'. The second is that most of the environmental problems that international cooperation attempts to solve have been caused, albeit unintentionally, by the rich and more powerful countries. It follows therefore that avoiding questions of justice will most likely result in poor nations having to bear a greater burden of environmental harm and international cooperation.

Roberts, J. T. and B. Parks (2007) A Climate of Injustice: Global Inequality, North-South Policies, and Climate Policy (Cambridge, MA: MIT Press).

This is a rich and well-argued account of the role of inequality between poor and rich countries in global climate negotiations. It contains an extensive analysis of the structural and historical origins of North-South injustice. It is strongly argued that there is little chance of getting a workable global agreement to deal with climate change and a strong argument unless close attention is paid to the fundamental issues of inequality and getting a good balance between conservation and development objectives.

Okereke, C. (2008) Global Justice and Neoliberal Environmental Governance: Ethics, Sustainable Development and International Co-Operation (London: Routledge). 
This is the first book devoted - not to a moral argument about the importance of justice in global environmental governance - but to actually analyzing and identifying the different conceptions that actually underpin key global environmental agreements. Covering three important environmental regimes, Third UN Law of the Sea (UNCLOS III), Hazardous Waste Regime (Basel convention), and the global Climate Change Agreement (UNFCCC), it is shown that while a variety of conceptions of justice can be found in international environmental agreements, by far the most dominant are conceptions of justice that are consistent with neoliberalism and free market philosophy such as justice as property rights.

Agarwal, A. and N. Sunita (1991) Global Warming in an Unequal World: A Case of Environmental Colonialism (New Delhi: Centre for Science and Environment).

A trenchant critique of the data and argument presented by the World Resource Institute (WRI) which appears to suggest that big developing countries, especially India and China, have comparable historical contributions to global warming with industrialized countries. The authors say that the WRI study and publication was 'an excellent example of environmental colonialism' (italics in original) because it seeks to arm developed countries and especially the United States with (manipulated) data, upon which they can continue their goal to blame developing countries for causing global warming and perpetuate existing North-South inequality.

\section{Works cited}

Adger, W. N. (2001) 'Scales of governance and environmental justice for adaptation and mitigation of climate change', Journal of International Development 13, 7, 921-931.

Adger, W. N., J. Paavola, S. Huq and M. J. Mace (eds) (2006) Fairness in Adaptation to Climate Change (Cambridge, MA: MIT Press). 
Agar, N. (1997) 'Biocentrism and the concept of life', Ethics 108, 1, 147-168.

Alder, J. and D. Wilkinson (1999) Environmental Law and Ethics (Palgrave Law Masters) (Basingstoke: Palgrave Macmillan), 167-185. Available at http://www.leadjournal.org/content/09167.pdf.

Aristotle (1874/1998) Nicomachean Ethics Book IV, Translated by J. A. K. Thompson (Harmondsworth: Penguin).

Auer, M. R. (2000) 'Who participates in global environmental governance? Partial answers from international relations theory', Policy Sciences 33, 2, 155-180.

Bachram, H. (2005) 'Climate fraud and carbon colonialism: The new trade in greenhouse gases', Capitalism Nature and Socialism 15, 4, 5-20.

Bäckstrand, K. (2003) 'Civic science for sustainability: Reframing the role of experts, policymakers and citizens in environmental governance', Global Environmental Politics 3, 4, 24 41.

Bäckstrand, K. (2004) 'Scientisation vs. civic expertise in environmental governance: Ecofeminist, eco-modern and post-modern responses', Environmental Politics 13, 4, 695-714.

Bäckstrand, K. (2006) 'Democratizing global environmental governance? Stakeholder democracy after the world summit on sustainable development', European Journal of International Relations 12, 4, 467-498.

Barry, B. (1965) Political Argument (London: Routledge and Kegan Paul).

Barry, B. (1989) Theories of Justice: A Treatise on Social Justice, Vol. 1 (California Series on Social Choice and Political Economy) (Berkeley and Los Angeles: University of California Press).

Barry, J. (1999) Rethinking Green Politics: Nature, Virtue and Progress (London: Sage). 
Baxter, B. (2005) A Theory of Ecological Justice (Abingdon: Routledge).

Beck, U. (1992) Risk Society: Towards a New Modernity (London: Sage).

Beck, U. (1999) World Risk Society (Cambridge: Polity Press).

Beck, U. (2010) 'Remapping social inequalities in an age of climate change: For a cosmopolitan renewal of sociology', Global Networks 10, 2, 165-181.

Beitz, C. R (1999) 'Social and cosmopolitan liberalism', International Affairs 75, 3, 515-529.

Bernstein, S. (2001) The Compromise of Liberal Environmentalism (New York: Columbia University Press).

Bhagwati, J. (1991) The World Trading System in Risk (Hemel Hempstead: Harvester Wheatsheaf).

Bhagwati, J. (1993) 'The case for free trade', Scientific American 269 (November), 42-49.

Biermann, F. and I. Boas (2010) 'Preparing for a warmer world: Towards a global governance system to protect climate refugees', Global Environmental Politics 10, 1, 60-88. Böhm, S. and S. Dabhi (eds) (2009) Upsetting the Offset: The Political Economy of Carbon Markets (London: Mayfly).

Böhm, S. and S. Dabhi (2011) 'Fault lines in climate policy: What role for carbon markets?' Climate Policy 11, 6, 1389-1392.

Bookchin, M. (1987) 'Social ecology versus deep ecology: A challenge for the ecology movement', Green Perspectives: Newsletter of the Green Program Project, 4-5. Available at http://dwardmac.pitzer.edu/Anarchist_Archives/bookchin/socecovdeepeco.html Borione, D. and J. Ripert (1994) ‘Exercising Common but Differentiated Responsibility’, in I. Mintzer, J. A. Leonard and M. J. Chadwick (eds), Negotiating Climate Change: The Inside Story of the Rio Convention (Cambridge: Cambridge University Press). 
Bowler, P. J. (1992) The Fontana History of the Environmental Sciences (London: Fontana Press).

Brennan, A. (2003) ‘Chapter 2: Philosophy’, in E. Page and J. Proops (eds) Environmental Thought (Cheltenham: Edward Elgar), 15-33.

Bretherton, C. (2003) 'Movements, networks, hierarchies: A gender perspective on global environmental governance', Global Environmental Politics 3, 2, 103-119.

Bryant, B. and P. Mohai (eds) (1992) Race and the Incidence of Environmental Hazards: A Time for Discourse (Boulder, CO: Westview Press).

Bulkeley, H. and A. P. Mol (2003) 'Participation and environmental governance: Consensus, ambivalence and debate', Environmental Values 12, 2, 143-154.

Bull, H. (1977) The Anarchical Society: A Study of Order in World Politics (London: Macmillan).

Bull, H. (1983) 'Justice in international relations', in A. Hurrell and K. Alderson (eds) (2000) Hedley Bull on International Society (Basingstoke: Macmillan).

Bullard, R. D. (1983) Confronting Environmental Racism: Voices from the Grassroots (Boston: South End Press).

Buzan, B. and R. Little (2001) 'Why international relations has failed as an intellectual project and what to do about it', Millennium Journal of International Studies 30, 1, 19-39. Byrne, J., L. Glover and C. Martinez (eds) (2002) Environmental Justice: Discourses in International Political Economy, Energy and Environmental Policy Series (Book 8) (New Brunswick, NJ: Transaction Books).

Callicott, J. B. (1989) In Defense of the Land Ethic: Essays in Environmental Philosophy (Albany: State University of New York Press). 
Caney, S. (2001) 'Review article: International distributive justice', Political Studies 49, 5, 974-981.

Caney, S. (2005) 'Cosmopolitan justice, responsibility, and global climate change', Leiden Journal of International Law 18, 4, 747-775.

Carson, R. (1962) Silent Spring (Boston, MA: Houghton Mifflin).

Cashore, B. (2002) 'Legitimacy and the privatization of environmental governance: How non - state market - driven (NSMD) governance systems gain rule - making authority', Governance 15, 4, 503-529.

Ceva, E. (2012) 'Beyond legitimacy. Can proceduralism say anything relevant about justice?', Critical Review of International Social and Political Philosophy 15, 2, 183-200 Charlesworth, M. and C. Okereke (2010) 'Policy responses to rapid climate change: An epistemological critique of dominant approaches', Global Environmental Change 20, 1, 121129.

Clark, N. (2008) ‘Aboriginal cosmopolitanism', International Journal of Urban and Regional Research 32, 3, 737-744.

Conca, K., M. Alberty and G. Dabelko (eds) Green Plant Blue, Environmental Politics from Stockholm to Rio (Boulder: Westview Press).

Clapp, J. (1998) 'The privatization of global environmental governance: ISO 14000 and the developing world', Global Governance 4, 3, 295-316.

Dasgupta, C. (1994) 'The climate change negotiations', in I. Mintzer and J. A. Leonard (eds) Negotiating Climate Change: The Inside Story of the Rio Convention (Cambridge: Cambridge University Press). 
De George, R. (1981) 'The environment, rights, and future generations', in E. Partridge (ed.) Responsibilities to Future Generations. Environmental Ethics (New York: Prometheus Books), 157-166.

den Elzen, M. G. J., M. Schaffer and P. L. Lucas (2005) 'Differentiating future commitments on the basis of countries relative historical responsibility for climate change: Uncertainties in the Brazil proposal in the context of a policy implementation', Climatic Change 71, 277-301.

Dobson, A. (1991) The Green Reader (London: André Deutsch).

Dobson, A. (1998) Justice and the Environment: Conceptions of Environmental

Sustainability and Dimensions of Social Justice (Oxford: Oxford University Press).

Dobson, A. (2005) 'Globalisation, cosmopolitanism and the environment', International Relations 19, 3, 259-273.

Dove, M. R. (2006) 'Indigenous people and environmental politics', Annual Review of Anthropology 35, 191-208.

Elliot, L. (1998) The Global Politics of the Environment (London: Palgrave Macmillan). Farber, D. A. (2007) 'Basic compensation for victims of climate change', University of Pennsylvania Law Review 155, 6, 1605-1656.

Friman, M. and B. Linner (2008) 'Technology obscuring equity: Historical responsibility in UNFCCC negotiations', Climate Policy 8, 339-354.

Gardiner, S. M. (2004) 'Ethics and global climate change', Ethics 114, 555-600.

Geldart, C. and P. Lyon (1981) 'The Group 77: A perspective view', International Affairs 57, $1,79-101$.

Gosseries, A. (2006) 'Constitutionalizing future rights?', Intergenerational Justice Review 3, 2, 10-11. 
Gosseries, A. (2008) 'On future generations' future rights', Journal of Political Philosophy $16,4,446-474$.

Grasso, M. (2007) 'A normative ethical framework in climate change', Climatic Change 81, $223-246$.

Grieco, J. M. (1988) 'Anarchy and the limits of co-operation: A realist critique of the newest liberal institutionalism', International Organization 42, 3, 485-507.

Guha, R. and J. Martinez-Alier (1997) Varieties of Environmentalism (London: Earthscan).

Grubb, M., J. K. Sebenius and A. Magalhaes (1991) Who Bears the Burden? Equity and Allocation in Greenhouse Gas Emissions and Abatement. Paper for SEI project for UNCED.

Hamlin, T. B. (1989) 'Debt-for-nature swaps: A new strategy for protecting environmental interests in developing nations', Ecology Law Quarterly 16, 1065-1089.

Hayes, P. (1993) 'North-South transfer', in P. Hayes and K. Smith (eds) The Global Greenhouse Regime: Who Pays? (London: Earthscan).

Hovi J., D. Sprinz and A. Underdal (2003) 'The Oslo-Potsdam solution to measuring regime effectiveness: Critique, response, and the road ahead', Global Environmental Politics 3, 3, 74-96.

Hurrell, A. (2001) 'Global inequality and international institutions', Metaphilosophy 32, 1-2, $34-57$.

Hume, D. (1975) ‘An enquiry concerning principles of morals', in A. Ryan (ed.) Justice (Oxford: Oxford University Press).

Jordan, L. and P. Van Tuijl (2000) 'Political responsibility in transnational NGO advocacy', World Development 28, 12, 2051-2065. 
Keohane, R. O. (1984) After Hegemony Co-operation and discord in the World Political Economy (New Jersey: Princeton University Press).

Kiss, A. (1985) 'The common heritage of mankind: Utopia or reality?', International Journal $40,423-441$.

Knicley, J. E. (2012) 'Debt, nature, and indigenous rights: Twenty-five years of debt-fornature evolution', Harvard Environmental Law Review, 36, 79-122

Lane, M. B. and T. Corbett (2005) 'The tyranny of localism: Indigenous participation in community-based environmental management', Journal of Environmental Policy and Planning 7.2, 141-159.

Leech, D. (2002) 'Designing the voting system for the Council of the European Union', Public Choice 113, 3-4, 437-464.

Lehr-Lehnardt, R. (2005) 'NGO legitimacy: Reassessing democracy, accountability and transparency', In Cornell Law School Inter-University Graduate Student Conference Papers.

Leopold, A. (2001) A Sand County Almanac: With Essays on Conservation (New York: Oxford University Press).

Levy, D. and P. Newell (eds) (2005) The Business of Global Environmental Governance (Cambridge, MA: MIT Press).

Litfin, K. (1994) Ozone Discourse: Science and Politics in Global Environmental Cooperation (New York, NY: Columbia University Press).

Lohmann, L. (2009) 'Toward a different debate in environmental accounting: The cases of carbon and cost-benefit', Accounting, Organizations and Society 34, 3, 499-534.

Lohmann, L. (2010) 'Uncertainty markets and carbon markets: Variations on Polanyian themes.' New Political Economy 15, 2, 225-254. 
Low, N. P. and B. Gleeson (1998) Justice Society and Nature: An Exploration of Political Ecology (New York: Routledge).

Lynas, M. (2009) 'How Do I know China Wrecked the Copenhagen Deal? I Was in the Room', Guardian, http://www.guardian.co.uk/environment/2009/dec/22/copenhagenclimate-change-mark-lynas

Masika, R. (ed.) (2002) Gender, Development, and Climate Change (Oxford: Oxfam).

Meadows, D. H., D. L. Meadows, J. Randers and W. W. Behrens III (1972) Limits to Growth (New York: New American Library).

Miller, D. (1999) Principles of Social Justice (Cambridge, MA: Harvard University Press).

Müller, B. (2001) 'Varieties of distributive justice in climate change', Climatic Change 48, 2, $273-288$.

Myers, N. (2002) 'Environmental refugees: a growing phenomenon of the 21st century', Phil. Trans. R. Soc. Lond. B 357, 1420, 609-613.

Naess, A. (1973) 'The shallow and the deep, long range ecology movement: A summary', Inquiry 16, 95-99.

Nagel, T. (2005) 'The problem of global justice', Philosophy \& Public Affairs 33, 2, 113 147.

Najam, A. (2005) 'Developing countries and global environmental governance: From contestation to participation to engagement', International Environmental Agreements: Politics, Law and Economics 5,3, 303-321.

Nelson, W. N. (1974) 'Special rights, general rights, and social justice’, Philosophy \& Public Affairs 3, 4, 410-430. 
Newell, P. and M. Paterson (2010). Climate Capitalism: Global Warming and the Transformation of the Global Economy (Cambridge: Cambridge University Press).

Newig, J. and O. Fritsch (2009) 'Environmental governance: Participatory, multi-level-and effective?', Environmental Policy and Governance 19, 3, 197-214.

Nozick, R. (1974) Anarchy State and Utopia (New York: Basic Books).

Okereke, C. (2008a) Global Justice and Neoliberal Environmental Governance: Ethics, Sustainable Development and International Co-Operation (London: Routledge).

Okereke, C. (2008b) 'Equity norms in global environmental governance’, Global Environmental Politics 8, 3, 25-50.

Okereke C. (2011) 'Moral foundations of global environmental and climate justice', Royal Institute of Philosophy Supplement 69, 117-135

Okereke, C. and D. McDaniels (2012) 'To what extent are EU steel companies susceptible to competitive loss due to climate policy?', Energy Policy 46, 203-215.

Okereke C. and H. Schroeder (2009) 'How can the objectives of justice, development and climate change mitigation be reconciled in the treatment of developing countries in a postKyoto settlement?', Climate and Development 1, 10-15.

O’Riordan, T. (1977) 'Environmental ideologies', Environment and Planning 9, 1, 3-14.

O’Riordan, T. (1981) Environmentalism (London: Pion Books).

Page, E. A. (2006) Climate Change, Justice, and Future Generations (Cheltenham: Edward Elgar).

Page, E. A. (2007) 'Fairness on the day after tomorrow: Justice, reciprocity and global climate change', Political Studies 55, 225-242. 
Page, E. A. (2011) 'Cosmopolitanism, climate change, and greenhouse emissions trading', International Theory 3, 1, 37-69.

Parks, B. C. and J. T. Roberts (2006) 'Environmental and ecological justice’, in M. M.

Betsill, K. Hochstetler and S. Demitris (eds) Palgrave Advances in International

Environmental Politics (Basingstoke: Palgrave Macmillan).

Paterson, M. (2000) Understanding Global Environmental Politics: Domination,

Accumulation and Resistance (Basingstoke: Macmillan).

Paterson, M. (2006) 'Theoretical perspective of international environmental politics', in M.

M. Betsill, K. Hochstetler and S. Demitris (eds) Palgrave Advances in International

Environmental Politics (Basingstoke: Palgrave Macmillan).

Paavola, J. (2005) 'Seeking justice: International environmental governance and climate change', Globalizations 2, 3, 309-322.

Paavola, J. and W. N. Adger (2006) 'Fair adaptation to climate change', Ecological Economics 56, 4, 594-609.

Pepper, D. (1984) The Roots of Modern Environmentalism (London: Routledge).

Pogge, T. (2001) 'Priorities of global justice', Metaphilosophy 32, 1/2, 6-24.

Potter, R., T. Binns, J. Elliott, and D. Smith (2008) Geographies of Development: an Introduction to Development Studies (3rd ed.) (New York: Prentice Hall).

Regan, T. (1987) 'The case for animal rights', Advances in Animal Welfare Science 3, 179189.

Ridely, M. and B. Low (1993) 'Can selfishness save the environment?', Human Ecology Review 1, 1, 1-13. 
Roberts, J. T. and B. Parks (2007) A Climate of Injustice: Global Inequality, North-South Policies, and Climate Policy (Cambridge MA: MIT Press).

Rawls, J. (1971) A Theory of Justice (Oxford: Oxford University Press).

Sachs, W. (ed.) (1993) Global Ecology: A New Arena of Political Conflict (London: Zed Books).

Sachs, W. (1999) Planet Dialectics: Explorations in Environment and Development (London: Zed Books).

Salter, R., B. Schutz and S. Dorr (eds) (1993) Global Transformation and the Third World (Boulder: Lynne Rienner Ltd).

Sandbach, F. (1980) Environment, Ideology and Policy (Oxford: Basil Blackwell).

Schlosberg, D. (2007) Defining Environmental Justice: Theories, Movements and Nature (Oxford: Oxford University Press).

Shrader-Frechette, Kristin (2002) Environmental Justice: Creating Equity, Reclaiming Democracy (New York: Oxford University Press).

Shue, H. (1992) 'The unavoidability of justice' in A. Hurrell and B. Kingsbury (eds) International Politics of the Environment: Actors Interests and Institutions (Oxford: Clarendon Press).

Shukla, P. R. (1999) 'Justice, equity and efficiency in climate change: A developing country perspective', in F. L. Toth (ed.) Fair Weather? Equity Concerns in Climate Change (London: Earthscan).

Singer, P. (1975) Animal Liberation: A New Ethics for our Treatment of Animals (New York: Random House). 
Skinner, E. (2011) Gender and Climate Change: Overview Report (Brighton: Institute of Development Studies).

Snidal, D. (1985) 'Coordination versus prisoners dilemma: Implications for international cooperation and regimes', American Political Science Review 79, 923-942.

St Augustine (1467/2003) The City of God, Translated by Henry Bettenson (London: Penguin).

Strong, M. (1999) 'Hunger, poverty, population and environment', The Hunger Project Millennium Lecture (Madras, India).

Sunstein, C. R. and C. M. Nussbaum (eds) (2004) Animal Rights: Current Debates and New Directions (New York, NY: Oxford University Press).

Thomas, D. S. and T. Chasca (2005) 'Equity and justice in climate change adaptation amongst natural-resource-dependent societies', Global Environmental Change 15, 2, 115124.

Tol, R. S. and R. V. Roha (2004) 'State responsibility and compensation for climate change damages - a legal and economic assessment', Energy Policy 32, 9, 1109-1130.

UNFCCC (1992) United Nations Framework Convention on Climate Change, Available at www.unfccc.int - $\underline{\text { http://unfccc.int/resource/docs/convkp/conveng.pdf }}$

Vanderheiden, S. (2008) Atmospheric Justice: A Political Theory of Climate Change (New York: Oxford University Press).

Viotti, P. R. and M. V. Kauppi (2011) International Relations Theory: Realism, Pluralism and Globalism (New York: Macmillan). 
Walker, G. and H. Bulkeley (2006) 'Geographies of environmental justice', Geoforum 37, $655-659$.

Wapner, P. (1995) 'Politics beyond the state', World Politics, 311-340 47, 3.

Wapner, P. (1996) Environmental Activism and World Civic Politics (Albany: State University of New York Press).

Wapner, P. (2006) 'A meaningful democratic platform on climate change' (with Benjamin Goldstein) in Tikkun 12, 5, September/October.

Warpner, P. (2007) 'The UN and civil society', in T. Weiss and S. Daws (eds) The Oxford Handbook on the United Nations (New York: Oxford University Press).

WCED (1987) Our Common Future: The World Commission on Environment and Development (Oxford: Oxford University Press).

Willetts, P. (1978) The Non-aligned Movement: The Origins of a Third World Alliance (London: F. Pinter).

Wise, S. M. (2003) Drawing the Line: Science and the Case for Animal Rights (Cambridge, MA: Perseus Books). 